\title{
MTAI promotes proliferation and invasion in human gastric cancer cells [Retraction]
}

Yao Y, Feng S, Xiao M, et al. MTA1 promotes proliferation and invasion in human gastric cancer cells. OncoTargets and Therapy. 2015;8:1785-1794.

This article has been retracted at the request of the Editorin-Chief of OncoTargets and Therapy. A case of image duplication in Figure 5 was brought to the attention of the Editorial team. Due to the extent of the discrepancies, the scientific validity of the data and hence the conclusions, are questionable. We apologise to the readers of the journal for not detecting it at submission/reviewing stage and any inconvenience caused.
OncoTargets and Therapy

\section{Publish your work in this journal}

OncoTargets and Therapy is an international, peer-reviewed, open access journal focusing on the pathological basis of all cancers, potential targets for therapy and treatment protocols employed to improve the management of cancer patients. The journal also focuses on the impact of management programs and new therapeutic agents and protocols on

\section{Dovepress}

patient perspectives such as quality of life, adherence and satisfaction. The manuscript management system is completely online and includes a very quick and fair peer-review system, which is all easy to use. Visit http://www.dovepress.com/testimonials.php to read real quotes from published authors. 